\title{
Effects of One Stop Border Posts (OSBPs) Trade Facilitation Initiative on the Movement of Goods along the Rwandan Customs Posts
}

\author{
Nkundabaramye Vincent ${ }^{1}$, Mom Aloysius Njong ${ }^{2}$ \\ ${ }^{1}$ Kigali Independent University (ULK), Kigali, Rwanda \\ ${ }^{2}$ University of Bamenda, Bamenda, Cameroon \\ Email: vincentnkundabaramye@gmail.com
}

How to cite this paper: Vincent, N. and Njong, M.A. (2021) Effects of One Stop Border Posts (OSBPs) Trade Facilitation Initiative on the Movement of Goods along the Rwandan Customs Posts. Open Access Library Journal, 8: e6708.

https://doi.org/10.4236/oalib.1106708

Received: November 9, 2021

Accepted: November 27, 2021

Published: November 30, 2021

Copyright $\odot 2021$ by author(s) and Open Access Library Inc.

This work is licensed under the Creative Commons Attribution International License (CC BY 4.0).

http://creativecommons.org/licenses/by/4.0/

\begin{abstract}
Despite a critical role played by cross-border movement of goods in international trade, the former is made complex and unpredictable by various factors. In Rwanda as is the case in other parts of the world, one stop border posts (OSBPs) adopted at the East African Community level have been implemented and operationalised to facilitate cross-border trade and movement of goods. This paper aims to assess the effects of OSBPs trade facilitation initiative on the movement of goods along the Rwandan customs posts using multi-level model. The main findings reveal that the implementation of OSBPs initiative has significantly and positively affected the movement of goods along the Rwandan customs posts giving an impression that the implementation of OSBPs trade facilitation initiative has considerably contributed to the improvements in the level of trade facilitation; and hence, streamlined and expedited the movement of goods along the Rwandan customs posts by removing unnecessary barriers.
\end{abstract}

\section{Subject Areas}

Economics

\section{Keywords}

One Stop Border Posts, Trade Facilitation, Trade Facilitation Initiative, Movement of Goods and Customs Posts

\section{Introduction}

Generally, the movement of goods along the transport corridors has increasingly been made complex and unpredictable by various factors. Some of the factors 
are formal, while others are informal. In the context of the EAC, the movement of goods along the Northern and Central transport corridors suffers from serious delays due to informal stops and checkpoints-formal or informal (World Bank, 2012) [1]; unnecessary en-route delays as a result of the existence of weighbridges, slow border-crossing times and police roadblocks (Gasiorek, et al., 2017) [2]. Unfavourable transport environment resulting into delays is also another factor with far-reaching negative effects on the movement of goods along the transport corridors. As such, Gasiorek, et al. (2017) [2], for instance, highlight that cargo transit times are almost twice as long as without these barriers.

Against the barriers the movement of goods along the transport corridors, great attention has been directed towards trade facilitation. The latter has been revealed to involve different actors to implement a set of rules, guidelines and procedures that promote trade rather than hampering it (Chimilila et al., 2014) [3]. Conceptualised as an effective approach to address the barriers to trade and movement of goods, trade facilitation has been put at the centre of the EAC development agenda since its re-establishment in 2000. The partner states have agreed to undertake and implement different trade facilitation initiatives, including the establishment of One Stop Border Posts (OSBPs) to combine the border posts of 2 partner states at a single location to address unnecessary barriers to trade and movement of goods.

In that context, the EAC has issued OSBPs Act (2012\&2016) to operationalize OSBPs initiative and 15 common border posts have consequently been designated as OSBPs (EAC, 2016) [4]. More specifically, Rwanda, as is the case in other EAC partner states, has been implementing OSBPs with full operationalization since 2014 to facilitate the movement of goods across the borders and customs posts. Accordingly, various OSBPs including Akanyaru, Nemba Ruhwa, Kagitumba, Gatuna and Rusumo ${ }^{1}$ have been designated.

Empirically, existing literature shows that the introduction of OSBPs has contributed to the improvements in trade facilitation and conditions for crossing borders and customs posts. According to a study by the United States Agency for International Development [USAID] (2013) [5], the OSBP facility has undoubtedly improved formal trade by streamlining processes and reducing costs. Kingombe (2014) [6], for instance, reveals that OSBPs permit commuting passengers and vehicles to stop only once; and inspection of customs is jointly accomplished. The Transport Logistics Consultants (2017) [7] also reveal that OSBPs result into significant improvements including $73 \%$ time reduction in cross border time for trucks, reduced time and quicker processing for transit by passengers.

In addition, several empirical studies have been conducted about the variables throughout the literature in the context of the EAC. Cheruiyot and Rotich (2018)

\footnotetext{
${ }^{1}$ Akanyaru, Nemba and Ruhwa are one stop border posts designed in South, South-East and South-West of Rwanda respectively, at the borders with Burundi; Gatuna and Kagitumba are one stop border posts designed in North and North-East of Rwanda, at the borders with Uganda; and Rusumo is one stop border post located in East, at the border with Tanzania.
} 
[8] conducted a study to assess the factors that affect the implementation of OSBP strategy and its impact on the Kenyan border. Mupayi and Manyeruke (2015) [9] did a study to assess the impact of the Chirundu OSBP in addressing border that constrained the flow of people and goods. Furthermore, Chimilila, et al. (2014) [3] did a study to address trade facilitation in the EAC Customs Union by tracking the achievements and implementation using Tanzania as a case.

The results of most studies have confirmed trade facilitation improvements resulting from the development of OSBPs facility. However, no study has specifically addressed the effects of OSBPs on the movement of goods in the EAC in general or in either of the partner states in particular. In addition, most of the studies did not involve various cross-border trade stakeholders. This study therefore contributes to the stock of knowledge by involving different trading agents to generate fresh data about the variables under the study and provides a comprehensive analysis of the effects of OSBPs trade facilitation initiative on the movement of goods along the Rwandan customs posts. The study also used multilevel modelling approach with two levels. Hence, this new approach of methodology also substantially contributes to the existing empirics.

The rest of this paper is structured as follows: Section 2 conceptualises trade facilitation, Section 3 addresses the concept of OSBP trade facilitation initiative, Section 4 deals with the concept of movement of goods and the factors affecting the movement of goods, Section 5 draws the linkage between OSBPs and the movement of goods, Section 6 discusses the theoretical foundation of this study, Section 7 presents the empirical literature in relation to the variables of the study, Section 8 presents the methodology, data source and sample frame, Section 9 presents the results and discussions and the Section 10 addresses the conclusion and recommendations.

\section{Trade Facilitation}

Worldwide, the term trade facilitation has, to a large extent, received unprecedented attention and conceptualised differently over time. The term trade facilitation is largely used by institutions that seek to improve the regulatory interface between government bodies and traders at national borders (Grainger, 2007) [10]. In addition, trade facilitation involves different actors to implement a set of rules, guidelines and procedures that promote trade rather than hampering it (Chimilila et al., 2014) [3]. Hence, the cross-sectoral nature of trade facilitation calls for close coordination between trade operators and service providers on the one hand and customs and various ministries and regulatory agencies on the other hand (United Nations Conference on Trade and Development [UNCTAD], 2006) [11].

In the context of the World Trade Organisation (WTO) and the Organisation for Economic Cooperation and Development (OECD), the term trade facilitation is defined as the "simplification of trade procedures," understood as the "activities, practices and formalities involved in collecting, presenting, commu- 
nicating and processing data required for the movement of goods in international trade." This definition is not far different from the definition proposed by the United Nations Centre for Trade Facilitation and Electronic Business (UN/ CEFACT) which defined trade facilitation as the simplification, standardization and harmonisation of procedures and associated information flows required to move goods from seller to buyer and to make payment (OECD, 2001) [12].

Other proponents and practitioners conceptualise trade facilitation as means or any initiatives aimed to lowering trade costs and avoiding unnecessary restrictiveness by improving efficiency in international trade chain. For instance, the United Nations Office of the High Representative for the Least Developed Countries, Landlocked Developing Countries and Small Island Developing States [UN-OHRLLS] (2013) [13] refers trade facilitation to the reduction of monetary costs and bureaucratic hurdles that make trade more difficult and expensive. Equally important, Orliac (2012) [14] refers trade facilitation to policies and measures aimed at easing trade costs by improving efficiency at each stage of the international trade chain. The World Customs Organisation (WCO) also defines trade facilitation as the avoidance of unnecessary trade restrictiveness by applying modern techniques and technologies, while improving the quality of controls in an internationally harmonised manner.

\section{One Stop Border Posts Trade Facilitation Initiative}

The concept of one stop border post has recently inspired competing definitions and interpretations. As such, this concept has been defined and conceptualised differently throughout the literature. Kieck (2010) [15] admits that there is no single definition of what constitutes OSBP. The OSBP Source Book (2011) [16] defines OSBP as a border post that combines two stops for national border control processing into one and consolidates border control functions in a single public hall for exiting one country and entering another. The East Africa Trade Hub (2012) [17] contextualises OSBP as a physical location at a border that houses border agencies from both countries. In international coordinated border or customs management point of view, OSBPs have been introduced as a mechanism to improve the movement of goods across shared borders (Kieck, 2010) [15].

OSBP Sourcebook also identifies four pillars on which OSBP facility is built, which all seek to boost efficiency and facilitate cross-border trade and movement of goods. Those pillars include legal and institutional framework; simplification and harmonization of procedures; information and communications technology and data exchange; and hard infrastructure (OSBP Sourcebook, 2016) [18]. While there is no specific definition of OSBP, one of the imperative features of OSBPs is the principle of extraterritoriality (Polner, 2011) [19]. However, the reasoning behind establishing different kinds of OSBPs revolves around increasing the effectiveness of the border crossings by reducing the number of stops and participating agencies (Polner, 2011) [19] and to expedite the movement of goods and people, and to reduce transport costs across national boundaries (OSBP Source- 
book, 2016) [18].

At the core of the one stop concept is the ability of border authorities from two countries to perform joint controls (Cheruiyot and Rotich, 2018) [8]; to provide for the sharing of ideas, information, experiences and infrastructure and law enforcement assets (Kieck, 2010) [15]; and to eliminate the need for travelers and goods to stop twice to undertake border crossing formalities (OSBP Soucebook, 2016) [18]. As such, one stop concept significantly reduces waiting times and costs (Kieck, 2010) [15]. However, international experience demonstrates that the full benefits of OSBPs initiative require all border control functions to be relocated to a one stop facility (Kieck, 2010) [15]. Beyond this, there is a need for simplified and joint processing in addition to close cooperation and exchange of data between both countries. There is also a need for political will, supports and cooperation as well as readiness to contribute to the operational costs from both countries.

\section{Movement of Goods}

There is throughout the literature a noticeable shortage in terms of conceptualisation of the concept movement of goods. According to Woudsma (2001) [20], this is because the elements of freight movement and the actors involved are much more complex, which makes it a difficult subject to research. However, the movement of goods can be conceptualised as flow of goods from one place to another. Grainger (2007) [10] identified that the international movement of goods includes a number of steps. Prior to export, this includes packing, storage, haulage to the port, port entry and customs clearance, and loading onto a vessel. And once arrived in the port of destination, operations include off-loading, storage, release from the port and customs clearance, delivery to the buyer, unpacking, after-sales services and more (Grainger, 2007) [10].

In addition, the international movement of goods also involves various operations and services which in one way or another make it complex and unpredictable. This, therefore, calls for a wide range of intermediaries, which include transport operators, trucking and haulage companies, freight forwarders, customs brokers, banks and finance companies, insurance companies, port operators and stevedores, and IT systems suppliers (Grainger, 2007) [10] to intervene in the process of moving goods along the transport corridors.

Moreover, international movement of goods depends on a transit system as well as transit regime. The later refers to the set of rules and regulations that govern the movement of goods from their origin in the transit country (often a seaport) to their destination (such as a clearance centre in the destination country) and the former refers to the infrastructure, legal framework, institutions and procedures serving trade corridors (Arvis, Smith and Carruthers, 2011) [21]. It is also imperative to mention that the transit system requires an exchange of information from at least three places: a place of transit initiation, a place of transit termination, and a place of the guarantor (Arvis, Smith and Carruthers, 2011) [21]. Hence, any inefficiency in trade facilitation measures like information ex- 
change between the three places and an ineffective implementation of trade facilitation initiatives like OSBPs make the movement of goods complex and unpredictable.

\section{Linkage between OSBPs Initiative and Movement of Goods}

According to the United Nations Conference on Trade and Development (2006) [11], trade facilitation is a diverse and challenging subject with potential benefits for both business and government at national, regional and international levels. Trade facilitation eases the cross-border movement of goods by cutting costs and simplifying trade procedures (Engman, 2005) [22]. Trade facilitation also simplifies and rationalises customs and other administrative procedures that hinder, delay or increase the cost of moving merchandise across international borders (Asia-Pacific Economic Cooperation [APEC], 2011) [23]. This therefore provides an evidence that the implementation of trade facilitation initiatives like OSBPs has potential to improve the level of trade facilitation and hence affects the movement of goods.

More specifically, in addition to improving border crossing procedures and processes which hinder the movement of goods, the introduction of OSBPs trade facilitation initiative is expected to reduce and ultimately eliminate unnecessary barriers to cross-border movement of goods such as delays, uncertainties, inefficient border operations and services, and multiple and complex clearance and customs procedures among other things. This, in turn, allows expediting movement of goods at the border by shifting controls by the border authorities at an earlier or later stage, thus reducing waiting times at the border (Lesser and MoiséLeeman, 2009) [24].

The introduction of OSBPs is also seen as a tool to expedite the movement of goods and people along transport corridors, and to reduce transport costs across national boundaries (OSBP Sourcebook, 2016) [18]. The implementation of OSBP has also been found to have both economic and customs law enforcement benefits (Cheruiyot and Rotich, 2018) [8]. The OSBP initiative promotes a coordinated and integrated approach to facilitating trade, the movement of people, and improving security; and eliminates the need for travellers and goods to stop twice to undertake border crossing formalities (OSBP Soucebook, 2016) [18]. Moreover, the OSBPs initiative significantly reduces waiting times and costs by moving away from the current two stops that are required to cross the border and comply with the regulatory requirements of the two neighbouring countries (Kieck, 2010) [15]. Hence, the OSBPs initiative is undoubtedly linked with the movement of goods along the transport corridors.

\section{Theoretical Framework}

Theoretical foundation of this study consists of the theories of international trade. In fact, there are various theories of international trade that explain the 
mechanism of global trade. Morgan and Katsikeas (1997) [25] shows that international trade issues generally pose three fundamental questions which, turn around the explanations of trade flows between at least two nations, the nature and extent of gains or losses of an economy, and the effects of trade policies on an economy. However, this study focuses on the theories of absolute and comparative advantages to explain the possible effects (gains and losses) of trade facilitation or liberalisation.

Worldwide, nations trade with each other because they benefit from it. In spite of other motives, the basic motive for international trade is that of the benefit, or gain, to the participants (Robert and John, 2004) [26]. As a result, the direction of unrestricted international trade is determined by the current absolute advantages (Schumacher, 2012) [27]. Accordingly, trading countries will be better off if each can specialise in the production of the products and services it produces efficiently and if they trade with one another. The specialisation is, therefore, a key for realising mutual benefits from the international trade. As such, a country can gain an absolute advantage in the production of a good, for example, or it can lose such an advantage, even as a direct effect of trade (Schumacher, 2012) [27].

The theory of absolute advantage has been the starting point for the theory of international trade. However, this theory has got some weaknesses in the sense that it has been unable to provide any insightful explanations as to what would happen in case one country among the trading countries has absolute advantage in all the products or areas. It is, therefore, in that regard that the Ricardo's theory of comparative advantage came into existence to provide a practical solution to such an issue. Suranovic (2010) [28] argues that this theory offers some of the most compelling reasons supporting international trade.

David Ricardo clearly explained that absolute advantages are not a necessary condition for two nations to gain from trade with each other. Instead, trade depends on differences in comparative advantage (Robert and John, 2004) [26], differences from the rest of the world (Harrigan, 2001) [29]; and one nation can profitably trade with another even though its real costs are higher (or lower) in every commodity (Robert and John, 2004) [26]. In addition, Gupta (2015) [30] also shows technological superiority, resource endowments, demand patterns, and commercial policies as the reasons why a country may have an advantage in exporting a commodity to another country.

The theory of comparative advantage has, however, got some weaknesses to explain the international trade. The most fundamental problem about comparative advantage is that it relates observables (trade flows and specialization patterns) to things which are by their nature almost always unobservable (Harrigan, 2001) [29]. In addition, its assumptions are proven to be unrealistic or useless and hence of little help for explaining free international trade (Schumacher, 2012) [27].

The applicability of Ricardo's theory of comparative advantage in this study 
basically originates from the fact that it assumes a scenario of no trade barriers among the trading countries such that the factors of production are free to move across the national boundaries. This then indicates that in order to achieve this situation, there is a need for the implementation of trade facilitation initiatives like one stop border posts to remove internal border controls; and simplify, harmonise and standardise customs and clearance procedures. This will help to improve cross-border trade and movement of goods in their complexity through the removal of unnecessary barriers to trade.

\section{Empirical Review}

Different empirical studies show that implementation of OSBPs resulted into impressive benefits including simplified and harmonised procedures and processes and reduction in time for clearance, crossing the borders and number of documents required to lodge the clearance. A survey by the Shippers Council of the Eastern Africa (2015) [31] entitled "East Africa Logistics Performance survey" reveals that OSBPs constructed along major borders have boosted trade facilitation across borders due to increased harmonization of border control regulations and procedures and enabling expeditious and more effective border control mechanisms.

Another study by Kingombe (2014) [6] reveals that the recently inaugurated OSBP at the border of Burundi and Rwanda permit commuting passengers and vehicles to stop only once; and inspection of customs are jointly accomplished. Equally important, a study by Tyson (2015) [32] also shows that the OSBP has predominantly improved the economic livelihoods of the informal traders by increasing their opportunities for cross-border trade and enlarging the markets in which they are able to trade and seek employment opportunities.

A TradeMark East Africa Time and Traffic Survey, conducted in June 2016 shows that significant results have been achieved due to operationalization of OSBP at the Busia border. The average time to cross from Busia, Uganda to Busia, Kenya; and from Busia, Kenya to Busia, Uganda has considerably reduced by $80 \%$ and $79 \%$ respectively. TradeMark East Africa (2018) [33] also reveals that the implementation of OSBPs has reduced time for crossing borders and time for clearance by $62 \%$. OSBP at Nemba/Gasenyi border between Rwanda and Burundi is also recorded to have improved formal trade by streamlining processes and reducing costs (USAID, 2013) [5]; and considerably reduced the average border crossing times to 40 minutes (Gashayija, 2015) [34].

The establishment of Kobero and Kabanga OSBPs also generated many benefits to the trading community. Time taken to transit goods has reduced to $30 \%$ as the result of Kobero and Kabanga OSBPs (TradeMark East Africa, 2017) [35]. Time taken to cross the border reduced from 14 hours 20 minutes in 2011 to 3 hours 40 minutes in 2017, an average reduction of 74\%; and traffic volumes across the border have grown by $14 \%$ from 1570 vehicles per week in June 2016 to 1,784 vehicles per week in July 2017 (TradeMark East Africa, 2017) [35]. 
Moreover, the Transport Logistics Consultants (2017) [7] in their survey revealed that the development of OSBP at Rusumo border resulted into significant improvements, which include $73 \%$ time reduction in cross-border time for trucks. In sum, as far as international trade is concerned, available empirical studies have estimated various benefits of the operationalisation of OSBPs across the borders.

\section{Methodology}

\subsection{Research Design, Population and Sampling Techniques}

This study was conducted in Rwanda. Geographically, Rwanda is surrounded by the Democratic Republic of Congo in the West, the Republic of Burundi in the South, the Republic of Uganda in the North and the Federal Republic of Tanzania in the East. However, the study focuses on the common borders of Rwanda and other EAC partner states (Tanzania, Uganda and Burundi). The study employed descriptive research design with mixed approach (qualitative and quantitative). The study also targets different groups of trading agents as the population from which a sample size of respondents was selected. This indicates that the population was not homogeneous in nature. As such, stratified sampling technique was adopted, whereby the population was grouped into 4 distinct groups of trading agents (traders; transporters; freight forwarders; and clearing agents) that are individually more homogeneous than the total population. Purposive sampling technique was then applied to select the representative sample for each group of trading agents.

It is also imperative to mention that as the population was not certain in terms of number, the study adopted the formula suggested by Daniel and Cross (2013) [36] to determine the sample size when sampling is from an unknown population, or when sampled population is large enough.

$$
n=\frac{Z^{2} p q}{d^{2}}
$$

Whereby, $n=$ sample size,

$Z=$ the value on the $Z$ Table at $95 \%$ confidence level $=1.96$,

$d=$ desired level of precision or sampling error $=5 \%$ or 0.05 ,

$p=$ Variability of the population estimated at $10 \%$ or 0.1 ,

$q=1-p=0.9$.

$$
\begin{aligned}
n & =\frac{(1.96)^{2}(0.1)(0.9)}{(0.05)^{2}} \\
& =138.29 \simeq 139
\end{aligned}
$$

A sample size of 139 respondents comprising 49 traders; 30 transporters; 30 freight forwarders; and 30 clearing agents was selected. The uneven distribution of respondents across the groups of trading agents is due to the fact that the size of the population was estimated to be uneven across the groups. It is estimated that the group traders (importers, exporters and both) has a great number of 
population, while other groups are estimated to have the same size of the population.

\subsection{Data Collection Methods, Reliability and Normality}

A survey questionnaire made of five-point Likert scale items was administered to the participants in order to collect data. The questionnaire was divided into four sections. Section 1 observed and generated demographic information of respondents; Section 2 examined the level of the implementation of OSBPs trade facilitation initiative across the Rwandan Customs posts; Section 3 was intended to collect data on the perceptions of various trading agents on the level of trade facilitation along the Rwandan customs posts; and Section 4 was designed to gather data on the perceptions of various trading agents on the movement of goods along the Rwandan customs posts. To ensure reliability, data were tested for internal consistency reliability using Cronbach's Alpha which was found to be 0.864 (see Table 1), hence acceptable as recommended by George and Mallery (2003) [37].

As regard the validity, factor analysis scoring for items was adopted to restructure the questionnaire. The purpose of this test is to find out the scores of different items for restructuring the questionnaire whereby the acceptable value or score is 0.3 . This means that the items with the score below 0.3 were deleted to restructure the questionnaire in order to ensure validity. Furthermore, to ensure normality, Shapiro-Wilk and Kolmogorov-Smirnov tests were performed. The results of these tests were found to be greater than 0.05 . This therefore provides an evidence that data were approximately normally distributed.

\subsection{Data Analysis and Estimation Methods}

As regard the analysis, data gathered were first and foremost quantified by

Table 1. Test for internal consistency reliability.

\begin{tabular}{cccc}
\hline Items & $\begin{array}{c}\text { Cronbach's } \\
\text { Alpha }\end{array}$ & $\begin{array}{c}\text { Cronbach's } \\
\text { Standardized } \\
\text { Items }\end{array}$ & $\begin{array}{c}\text { Number } \\
\text { of Items }\end{array}$ \\
\hline $\begin{array}{c}\text { Items capturing the extent to which the } \\
\text { movement of goods has been facilitated along } \\
\text { the Rwandan customs posts }\end{array}$ & 0.824 & 0.820 & 10 \\
$\begin{array}{c}\text { Items capturing the level of trade facilitation } \\
\text { across the Rwandan Customs posts in the } \\
\text { framework of the One Stop Border Posts } \\
\text { (OSBPs) }\end{array}$ & 0.829 & 0.832 & 26 \\
$\begin{array}{c}\text { Overall Survey Questionnaire Cronbach's } \\
\text { Alpha }\end{array}$ & 0.784 & 0.864 & 26 \\
\hline
\end{tabular}

Source: Compiled from Field Data, 2018. 
determining average scores of the relevant items using Statistical Package for Social Sciences (SPSS). Thereafter, data were analysed using descriptive statistics (mean, standard deviation, 95\% confidence interval for mean and minimum and maximum means) to determine the level of the implementation of OSBPs, to examine the level of trade facilitation and to establish the extent to which the movement of goods has been facilitated along the Rwandan customs posts.

In addition, multi-level model was applied to estimate the extent to which OSBPs initiative affects the movement of goods across the Rwandan customs posts. As such, the following hypotheses were formulated and tested: null hypothesis "OSBPs trade facilitation initiative has no effect on the movement of goods across the Rwandan customs posts" and alternative hypothesis "OSBs trade facilitation initiative has significant positive effects on the movement of goods across the Rwandan customs posts." The relationship between OSBPs (X) and the movement of goods $(\mathrm{Y})$ was moderated by the level of trade facilitation (W). As such, these models were applied: null model (1), random intercept and fixed slope model (2), random intercept and slope model (3), and cross-level interaction model (4).

$$
\begin{gathered}
y_{i j}=\gamma_{00}+u_{0 j}+e_{i j} \\
y_{i j}=\gamma_{00}+\gamma_{10}\left(X_{i j}-\bar{X}_{j}\right)+\gamma_{01}\left(\mathrm{~W}_{j}-\bar{W}\right)+u_{o j}+e_{i j} \\
y_{i j}=\gamma_{00}+\gamma_{01}\left(W_{j}-\bar{W}\right)+\gamma_{10}\left(X_{i j}-\bar{X}_{J}\right)+u_{0 j}+u_{1 j}\left(X_{i j}-\bar{X}_{J}\right)+e_{i j} \\
y_{i j}=\gamma_{00}+\gamma_{01}\left(W_{j}-\bar{W}\right)+\gamma_{10}\left(X_{i j}-\bar{X}_{j}\right)+\gamma_{11}\left(X_{i j}-\bar{X}_{j}\right)\left(W_{j}-\bar{W}\right) \\
+u_{0 j}+u_{1 j}\left(X_{i j}-\bar{X}_{j}\right)+e_{i j}
\end{gathered}
$$

Whereby,

$y_{i j}$ : Response variable (movement of goods) score for the $i^{\text {th }}$ trading agent in group $;$

$\gamma_{00}$ : Grand mean movement of goods across the groups of trading agents;

$u_{0 j}$ : Group level (level 2) residual term;

$e_{i j}$ : Individual level (level 1) residual term (randomly distributed error);

$X_{i j}$ : Individual OSBPs trade facilitation initiative score for the $i^{\text {th }}$ trading agent in group $j$

$\bar{X}_{j}$ : Group average OSBPs trade facilitation initiative score;

$W_{j}$ : Group $j$ level of trade facilitation score;

$\bar{W}:$ Average group level of trade facilitation score;

$\gamma_{10}$ : Predicted slope regressing OSBPs trade facilitation initiative on the movement of goods;

$\gamma_{01}$ : The amount of change in the scores of the movement of goods associated with a 1-unit increase in the level of trade facilitation;

$\gamma_{11}$ : Cross-level interaction effects: moderating effect of the level of trade facilitation on the relationship between OSBPs trade facilitation initiative and the movement of goods. 


\section{Results and Discussions}

\subsection{Demographic Characteristics of Respondents}

This section describes the respondents in terms of their gender, age, experience, activity and transit corridor used in trading activities. It starts by describing the respondents in terms of gender characteristics as presented in Figure 1.

Figure 1 reveals that both male and female respondents participated in the study, though the majority of respondents, equivalent to $64.70 \%$, were male against $35.30 \%$ female respondents. Next, this section describes the respondents in terms of age. In order to understand age composition or characteristics of the respondents, the age of respondents were grouped into different age groups as shown in Figure 2. The latter shows that people (respondents) from different age groups have participated in this study. However, the majority of respondents (28.1\%) were aged 40 to 44 followed by those aged 30 - 34 and those aged 35 - 39 constituting $20.9 \%$ and $20.1 \%$ respectively. Those aged $45-49$ and 50 and above were respectively $12.9 \%$ and $5.8 \%$. In sum, the results indicate that most of the trading agents who participated in this study were in early adulthood.

Furthermore, this study involved different groups of trading agents (traders, transporters, freight forwarders and clearing agents) who use either of the Northern or Central Transport Corridor or both of them in moving their goods

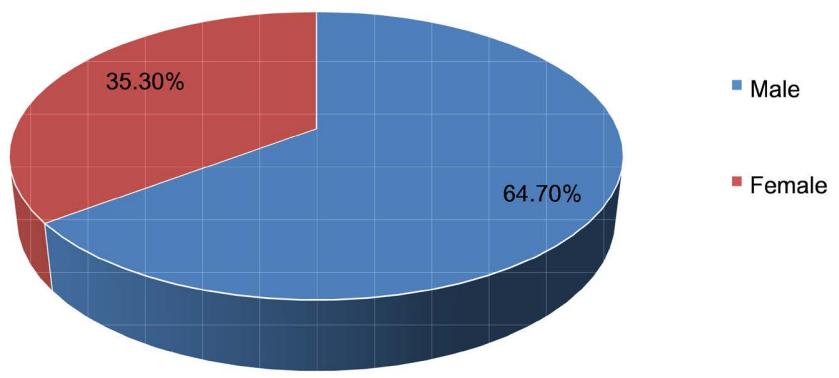

Figure 1. Gender of the Participants. Source: Field Data, 2018.

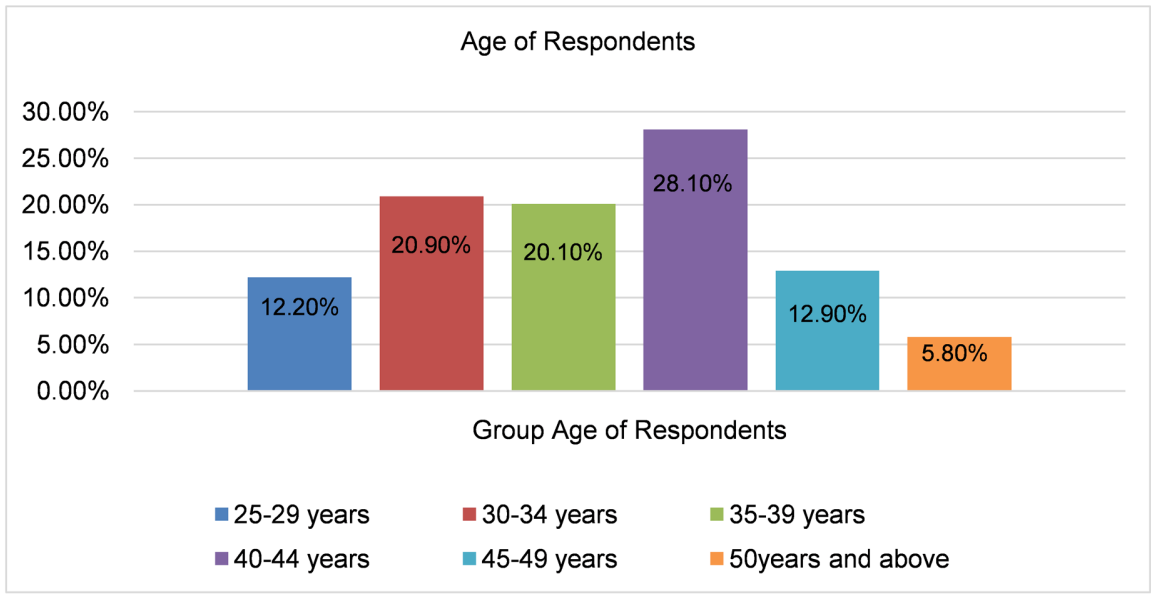

Figure 2. Age of the participants. Source: Field Data, 2018. 
to or from Rwanda. As such, the respondents were also described in terms of their groups of trading agents and transport corridor used. Table 2 summarises the numbers of respondents according to their groups and transport corridor used to move their goods.

Table 2 reveals that more than one-third (35.25\%) of all respondents were traders (importers, exporters/both) and the groups of transporters, freight forwarders and clearing agents have the same number of respondents constituting $21.58 \%$ each. It is evident that the respondents were engaged in various crossborder trading activities namely, trading, transporting, freight forwarding and clearing. However, the group of trading agents who were engaged in trading (exporting, importing and both of them) dominated the study.

In terms of transport corridor used by the trading agents to move the goods to or from Rwanda, the results in Table 2 indicate that a substantive proportion (about 46\%) of respondents use both Northern and Central transport corridors. On the other hand, those who use only Northern transport corridor were $30.22 \%$ against $23.74 \%$ who use only Central transport corridor. These results imply that a great proportion of Rwandan trading agents use both Mombasa and Dar-es Salam ports to move their goods to or from Rwanda.

In terms of duration (experience of respondents) in cross-border trading activities, Figure 3 shows that the majority of respondents have been performing trading activities for 7 - 9 years and 10 years and above, totalling $64.0 \%$ but each constituting about one-third of all respondents. However, $29.5 \%$ and $6.5 \%$ of all respondents have been performing trading activities for 4 - 6 years and less than 4 years respectively. These results give an impression that trading agents who participated in this study had good knowledge about trade facilitation, one stop border posts facility and the movement of goods in general and across the Rwandan borders and customs posts in particular.

In the next section, data are analysed according to the objectives of the study.

Table 2. Distribution of respondents according to their groups and transport corridor used.

\begin{tabular}{|c|c|c|c|c|c|}
\hline \multirow[b]{2}{*}{ Group } & \multicolumn{3}{|c|}{ Corridor } & \multirow[b]{2}{*}{ Total } & \multirow[b]{2}{*}{ Percent } \\
\hline & $\begin{array}{l}\text { Northern } \\
\text { Corridor }\end{array}$ & $\begin{array}{l}\text { Central } \\
\text { Corridor }\end{array}$ & $\begin{array}{c}\text { Both of } \\
\text { them }\end{array}$ & & \\
\hline $\begin{array}{l}\text { Traders (Importers, } \\
\text { Exporters/Both) }\end{array}$ & 17 & 7 & 25 & 49 & 35.25 \\
\hline Transporters & 12 & 2 & 16 & 30 & 21.58 \\
\hline Freight forwarders & 4 & 18 & 8 & 30 & 21.58 \\
\hline Clearing Agents & 9 & 6 & 15 & 30 & 21.58 \\
\hline Total & 42 & 33 & 64 & 139 & 10 \\
\hline Percent & 30.22 & 23.74 & 46.04 & 100.0 & \\
\hline
\end{tabular}

Source: Field Data, 2018. 


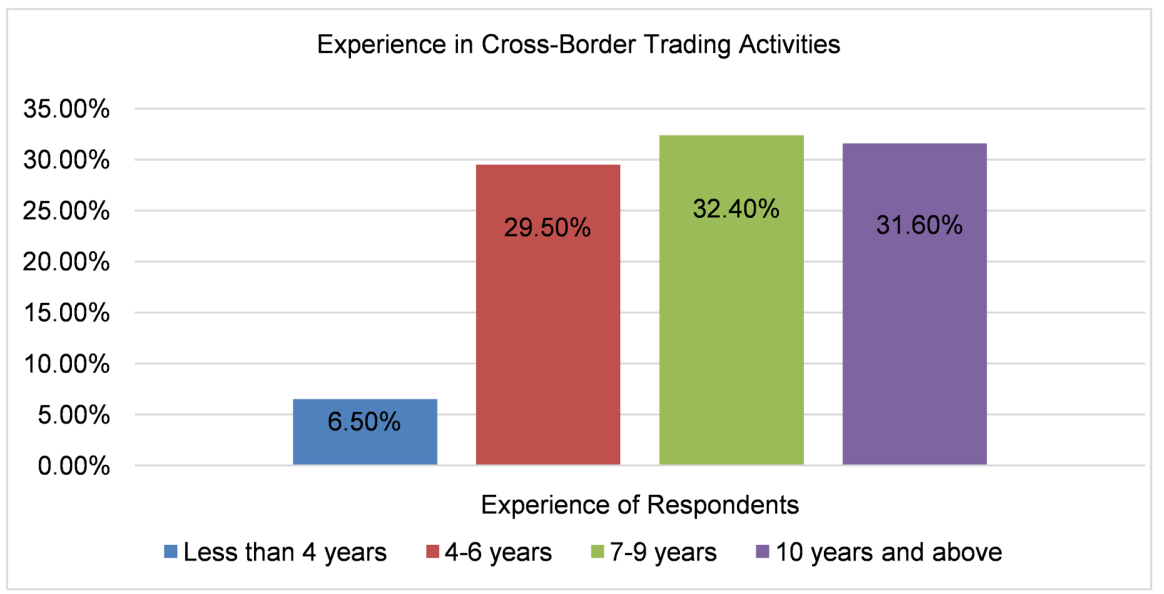

Figure 3. Experience of respondents in cross-border trading activities. Source: Compiled from Field Data, 2018.

Before embarking on the analysis, data collected with five-point Likert scale items questionnaire across the groups of trading agents as mentioned earlier were quantified. This was done through the calculation of average scores using the Statistical Package for Social Sciences (SPSS).

In order to examine the implementation level of OSBPs trade facilitation initiative, to determine the level of trade facilitation and to establish the extent to which the movement of goods has been facilitated, descriptive statistics including means were utilised. Hence, in order to interpret mean, statistical ranges of mean and their corresponding descriptive rating were established according to the suggestions of Parilla (2013) [38] and Saduak et al. (2017) [39] as follows. A mean of $1.00-1.80$ indicates a very poor/low level/extent; a mean of $1.81-2.60$ indicates a poor/low level/extent; a mean of 2.61 - 3.40 indicates moderate level/ extent; a mean of $3.41-4.20$ indicates a good/high level/extent; and a mean of $4.21-5.00$ indicates a very good/high level/extent.

\subsection{Implementation Level of OSBPs Initiative across the Rwandan Customs Posts}

Implementation level of OSBPs trade facilitation initiative across the Rwandan customs posts was established using descriptive statistics such as mean, standard deviation, 95\% confidence interval for mean and minimum and maximum means. The corresponding results are presented in Table 3.

Table 3 reveals that the level of the implementation of OSBPs trade facilitation initiative along the Rwandan customs posts is scored differently by the different groups of trading agents. More specifically, the level of the implementation of OSBPs trade facilitation initiative is scored is scored 4.51 by traders; 3.63 by transporters; 4.40 by freight forwarders; and 3.66 by clearing agents. The minimum mean scores of the level of the implementation of OSBPs trade facilitation initiative for the groups of traders and transporters are 3.0 and 1.0 respectively; and 2.0 for either of the groups of freight forwarders and clearing agents. 
Table 3. Implementation level of OSBPs initiative by trading agents.

\begin{tabular}{|c|c|c|c|c|c|c|c|c|}
\hline \multirow{2}{*}{ Trading Agents Group } & \multirow{2}{*}{$\mathrm{N}$} & \multirow{2}{*}{ Mean } & \multirow{2}{*}{$\begin{array}{c}\text { Std. } \\
\text { Deviation }\end{array}$} & \multirow{2}{*}{$\begin{array}{l}\text { Std. } \\
\text { Error }\end{array}$} & \multicolumn{2}{|c|}{$\begin{array}{l}\text { 95\% Confidence } \\
\text { Interval for Mean }\end{array}$} & \multirow{2}{*}{ Min. } & \multirow{2}{*}{ Max. } \\
\hline & & & & & $\begin{array}{l}\text { Lower } \\
\text { Bound }\end{array}$ & $\begin{array}{l}\text { Upper } \\
\text { Bound }\end{array}$ & & \\
\hline Traders (Importers, Exporters) & 49 & 4.5102 & 0.61652 & 0.08807 & 4.3331 & 4.6873 & 3.00 & 5.00 \\
\hline Transporters & 30 & 3.6333 & 0.80872 & 0.14765 & 3.3314 & 3.9353 & 1.00 & 5.00 \\
\hline Freight forwarders & 30 & 4.4000 & 0.45486 & 0.08305 & 3.8302 & 4.1698 & 2.00 & 5.00 \\
\hline Clearing Agents & 30 & 3.6667 & 1.06134 & 0.19377 & 3.2704 & 4.0630 & 2.00 & 5.00 \\
\hline Total & 139 & 4.0288 & 0.22143 & 0.07070 & 3.8890 & 4.1686 & 1.00 & 5.00 \\
\hline
\end{tabular}

Source: Field Data, 2018.

The maximum mean scores of the level of the implementation of OSBPs trade facilitation initiative is 5.0 for each of the four groups. The overall average score of the level of the implementation of OSBPs trade facilitation initiative is 4.02; and the overall minimum and maximum average scores are respectively 1.0 and 5.0 .

The results of the study suggest that the level of the implementation of OSBPs trade facilitation initiative across the Rwandan customs posts is in general and across the groups of trading agents rated good. These results imply that the implementation of OSBPs initiative along the Rwandan customs posts has been successful and to large extent contributed to the improvements in trade facilitation along the Rwandan customs posts. Empirically, these findings confirm the existing literature that the EAC policies have been successfully implemented when compared to other Sub-Saharan African RECs (Mathieson, 2016) [40]. Importantly, Rwanda performs significantly better than the average of Sub-Saharan and low income countries in the implementation of some trade facilitation measures like in the areas of information availability, streamlining of procedures, governance and impartiality ${ }^{2}$.

\subsection{The Level of Trade Facilitation across the Rwandan Customs Posts}

This section establishes the level of trade facilitation along the Rwandan customs posts. Descriptive statistics namely, mean, standard deviation, 95\% confidence interval for mean and minimum and maximum means were applied to establish the level of trade facilitation. The results achieved in this regard are summarised in Table 4.

According to Table 4, the degree to which the level of trade facilitation along the Rwandan customs posts has been perceived by the different groups of trading agents who participated in this study is almost the same. The level of trade

${ }^{2}$ Implementation of the WTO trade facilitation agreement,

https://www.oecd.org/tad/policynotes/oecd-tfi-implementation-impact-trade-costs.pdf, accessed on 14 October 2018. 
Table 4. Level of trade facilitation by trading agents.

\begin{tabular}{|c|c|c|c|c|c|c|c|c|}
\hline \multirow{2}{*}{ Trading Agents Group } & \multirow{2}{*}{$\mathrm{N}$} & \multirow{2}{*}{ Mean } & \multirow{2}{*}{$\begin{array}{c}\text { Std. } \\
\text { Deviation }\end{array}$} & \multirow{2}{*}{$\begin{array}{l}\text { Std. } \\
\text { Error }\end{array}$} & \multicolumn{2}{|c|}{$\begin{array}{l}\text { 95\% Confidence } \\
\text { Interval for Mean }\end{array}$} & \multirow{2}{*}{ Min. } & \multirow{2}{*}{ Max. } \\
\hline & & & & & $\begin{array}{l}\text { Lower } \\
\text { Bound }\end{array}$ & $\begin{array}{l}\text { Upper } \\
\text { Bound }\end{array}$ & & \\
\hline Traders (Importers, Exporters) & 49 & 4.1733 & 0.22721 & 0.03246 & 4.1081 & 4.2386 & 3.64 & 4.63 \\
\hline Transporters & 30 & 4.3385 & 0.20726 & 0.03784 & 4.2612 & 4.4159 & 3.96 & 4.68 \\
\hline Freight forwarders & 30 & 4.2954 & 0.21460 & 0.03918 & 4.2153 & 4.3755 & 3.81 & 4.64 \\
\hline Clearing Agents & 30 & 4.3246 & 0.18575 & 0.03391 & 4.2552 & 4.3939 & 4.01 & 4.78 \\
\hline Total & 139 & 4.2680 & 0.22143 & 0.01878 & 4.2308 & 4.3051 & 3.64 & 4.78 \\
\hline
\end{tabular}

Source: Field Data, 2018.

facilitation along the Rwandan customs posts has been scored 4.17 by traders, 4.33 by transporters, 4.29 by freight forwarders and 4.32 by clearing agents. Furthermore, the minimum mean scores of the level of trade facilitation across the groups of trading agents are $3.64 ; 3.96 ; 3.81$; and 4.01 respectively while, the maximum scores are 4.63; 4.68; 4.64; and 4.78 respectively. Moreover, the total average score of the level of trade facilitation along the Rwandan customs posts is 4.26 while, the overall minimum and maximum mean scores are 3.64 and 4.78 respectively.

In sum, the results of this study show that the level of trade facilitation across the Rwandan customs posts is rated very high in general and across the groups of trading agents. This means that there have been improvements through the simplification, harmonisation and standardisation of customs clearance procedures, trade documents and formalities for moving goods amongst others as well as the cooperation of customs authorities. These results support the findings that OSBPs constructed along borders have boosted trade facilitation (Shippers Council of the Eastern Africa, 2015) [31]; and permit commuting passengers and vehicles to stop only once; and inspection of customs are jointly accomplished (Kingombe, 2014) [6].

\subsection{Extent to Which the Movement of Goods Has Been Facilitated}

For the purpose of determining the extent to which the movement of goods has been facilitated along the Rwandan customs posts, different descriptive statistics including mean were adopted. These helped to analyse and understand the perceptions of different groups of trading agents on the extent to which the movement of goods have been made easier and smoother. The results obtained in that regard are summarised in Table 5 .

Refer to Table 5, the results indicate that the extent to which the movement of goods has been facilitated along the Rwandan customs posts is scored slightly different by various groups of trading agents. On average, the extent to which the movement of goods has been facilitated is scored 3.78 by traders, 4.01 by 
Table 5. Extent to which the movement of goods has been facilitated by trading agents.

\begin{tabular}{|c|c|c|c|c|c|c|c|c|}
\hline \multirow{2}{*}{ Trading Agents Group } & \multirow{2}{*}{$\mathrm{N}$} & \multirow{2}{*}{ Mean } & \multirow{2}{*}{$\begin{array}{c}\text { Std. } \\
\text { Deviation }\end{array}$} & \multirow{2}{*}{$\begin{array}{l}\text { Std. } \\
\text { Error }\end{array}$} & \multicolumn{2}{|c|}{$\begin{array}{l}\text { 95\% Confidence } \\
\text { Interval for Mean }\end{array}$} & \multirow{2}{*}{ Min. } & \multirow{2}{*}{ Max. } \\
\hline & & & & & $\begin{array}{l}\text { Lower } \\
\text { Bound }\end{array}$ & $\begin{array}{l}\text { Upper } \\
\text { Bound }\end{array}$ & & \\
\hline Traders (Importers, Exporters) & 49 & 3.7816 & 0.34198 & 0.04885 & 3.6834 & 3.8799 & 3.10 & 4.50 \\
\hline Transporters & 30 & 4.0167 & 0.41447 & 0.07567 & 3.8619 & 4.1714 & 3.20 & 4.80 \\
\hline Freight forwarders & 30 & 4.0033 & 0.31126 & 0.05683 & 3.8871 & 4.1196 & 3.30 & 4.60 \\
\hline Clearing Agents & 30 & 3.9033 & 0.30567 & 0.05581 & 3.7892 & 4.0175 & 3.50 & 4.80 \\
\hline Total & 139 & 3.9065 & 0.35635 & 0.03023 & 3.8467 & 3.9662 & 3.10 & 4.80 \\
\hline
\end{tabular}

Source: Field Data, 2018.

transporters, 4.00 by freight forwarders and 3.90 by clearing agents. The minimum mean scores are 3.10 for traders, 3.20 for transporters, 3.30 for freight forwarders and 3.50 for clearing agents and the maximum average scores are 4.50 for traders, 4.80 for transporters, 4.60 for freight forwarders and 4.80 for clearing agents. Nevertheless, the total average score of the extent to which the movement of goods has been facilitated along the Rwandan customs posts is 3.90 while, the total average minimum and maximum mean scores are respectively 3.10 and 4.80.

The results indicate that the extent to which the movement of goods has been facilitated along the Rwandan customs posts is generally rated high and across the groups of trading agents in particular. This therefore means that the barriers like time taken for clearance, documents, procedures and formalities amongst others for moving goods along the Rwandan customs posts have to a large extent been simplified. In line with these results, existing literature shows that the barriers to the movement of goods along the Rwandan customs posts have significantly reduced. More specifically, the time to move or transport goods has significantly reduced (Ombudoet al. 2014) [41] and Rwanda's performance is particularly good on the time it takes to comply with import procedures (English et al., 2016) [42].

\subsection{Extent to which OSBPs Initiative affects the Movement of Goods}

This section establishes the extent to which the OSBPs trade facilitation initiative affects the movement of goods across the Rwandan customs posts. Hence, in order to estimate such an extent, multi-level modelling was applied with two levels and 4 models as explained in the methodology section. The choice of the modelling was due to nested nature of data as they were collected across the different groups of trading agents. The results of multi-level model estimates are presented in Table 6.

Table 6-null model reveals that the overall mean movement of goods across the groups of trading agents is estimated at 3.920156; the within-group variance 
Table 6. Results of multi-level modelling analysis.

\begin{tabular}{|c|c|c|c|c|}
\hline & & Model & & \\
\hline Level and Variable & Null & $\begin{array}{l}\text { Random Intercept } \\
\text { and Fixed Slope }\end{array}$ & $\begin{array}{l}\text { Random Intercept } \\
\text { and Random Slope }\end{array}$ & $\begin{array}{l}\text { Cross-Level } \\
\text { Interaction }\end{array}$ \\
\hline \multicolumn{5}{|l|}{ Level 1 Effects } \\
\hline Intercept $\left(\gamma_{00}\right)$ & $3.920^{*}(0.04968)$ & $-1.230^{\star}(0.380)$ & $-1.168^{\star}(0.384)$ & $-3.132^{\star * *}(1.80)$ \\
\hline $\begin{array}{l}\text { The predicted slope regressing OSBPs on the } \\
\text { movement of goods }\left(\gamma_{10}\right)\end{array}$ & - & $-0.055^{\star \star}(0.023)$ & $-0.061^{\star \star}(0.029)$ & $0.421(0.432)$ \\
\hline \multicolumn{5}{|l|}{ Level 2 Effects } \\
\hline $\begin{array}{l}\text { The level of change in the movement of goods } \\
\text { associated with a } 1 \text {-unit increase in the level of } \\
\text { trade facilitation }\left(\gamma_{01}\right)\end{array}$ & - & $1.255^{\star}(0.084)$ & $1.246^{\star}(0.082)$ & $1.714^{*}(0.425)$ \\
\hline \multicolumn{5}{|l|}{ Cross-Level Interaction } \\
\hline Cross-level interaction effects $\left(\gamma_{11}\right)$ & - & - & - & $-0.115(0.103)$ \\
\hline \multicolumn{5}{|l|}{ Variance Components } \\
\hline Residuals/the within-group (L1) variance $\left(\sigma^{2}\right)$ & 0.119182 & 0.044 & 0.044 & 0.043 \\
\hline Intercept/the between-group (L2) variance $\left(\tau_{00}\right)$ & 0.006335 & 0.002 & 0.030 & 0.040 \\
\hline Slope $(\mathrm{L} 2)$ variance $\left(\tau_{11}\right)$ & - & - & 0.001 & 0.002 \\
\hline Intercept-slope (L2) variance $\left(\tau_{01}\right)$ & - & - & -0.006 & -0.008 \\
\hline Intra-class Correlation (ICC) & 0.05047 & - & - & - \\
\hline$-2^{\star} \log$ likelihood & 102.940 & -35.968 & -37.343 & 36.763 \\
\hline
\end{tabular}

Source: Field Data, 2018. Values in parentheses are standard errors. ${ }^{*}$ Significant at $\mathrm{P}<0.01$ level; ${ }^{* *}$ Significant at $\mathrm{P}<0.05$ level; and ${ }^{* * *}$ Significant at $\mathrm{P}<0.10$ level.

$\sigma^{2}$ is estimated at 0.119182 and the across-group variance in individual movement of goods $\tau_{00}$ is estimated at 0.006335 . Thus, the total variance is found to be equal to $0.119182+0.006335=0.125517$. From these results, the proportion of the total variation in the movement of goods scores accounted for by group differences can be estimated by computing the intra-class correlation (ICC) coefficient $(\rho)$ as follows: $\rho=\tau_{00} /\left(\tau_{00}+\sigma^{2}\right)$

The ICC is then equal to 0.05047 , meaning that $5.04 \%$ of the variation or differences in the movement of goods scores is between-groups and $94.96 \%$ is within-group. Accordingly, Peugh (2010) [43] shows the ICC values between .05 and .20 to be common in cross-sectional multi-level modelling applications in social research studies. Thus, the ICC of 0.05047 provides an evidence for applying multi-level modelling.

However, it is also important to test the significance of group-level effects on the movement of goods along the Rwandan customs posts. In order to estimate the group-level effects, the likelihood ratio test (LRT) is carried out through the comparison of the results of the two models (null multi-level model in Table 6 and null single-level model in Table 7). 
Table 7. Null single-level model.

\begin{tabular}{cccccc}
\hline Level & Variable & Estimate & Std. Err. & Z & P $>|Z|$ \\
\hline Level 1 Effects & Intercept $\left(\gamma_{00}\right)$ & $3.906475^{*}$ & 0.0301165 & 129.71 & 0.000 \\
\hline \multirow{2}{*}{ Variance Components } & Residuals/the within-group $(\mathrm{L} 1)$ variance $\left(\sigma^{2}\right)$ & 0.1260732 & - & - & - \\
& $-2^{\star} \log$ likelihood & 106.611 & - & - & - \\
\hline
\end{tabular}

Source: Field Data, 2018. ${ }^{\star}$ Significant at $\mathrm{P}<0.01$.

More specifically, the LRT is carried out as the difference between the $-2 * \log$ likelihood value in both models, i.e. in null model (Table 6) and in null single-level model (Table 7). Hence, the LRT is equal to $106.611-102.940=3.67$ on 1 d.f. as there is only one parameter difference between both models. However, there is $5 \%$ point of chi-squared distribution on 1 d.f. which is equal to 3.84. Thus, through the comparison of the critical p-value with the likelihood ratio value, it is evident that there is no trading agents' group effects. Hence, a multi-level model with no trading agents' group-level effects is most appropriate. Accordingly, null model is further extended to random intercept and fixed slope model to estimate the effects of implementation of OSBPs trade facilitation initiative on the movement of goods. To do so, the intercept of regression of the scores of the extent of trade facilitation were allowed to vary randomly across the groups of trading agents in order to estimate the factors that explain the variances $\sigma^{2}$ and $\tau_{00}$.

The results of the random intercept and fixed slope model (Table 6) indicates that the mean movement of goods for a group of trading agents $\left(\gamma_{00}\right)$ is estimated at -1.230 and the predicted slope regressing the movement of goods on OSBPs $\left(\gamma_{10}\right)$ is estimated at -0.055 . These results give an impression that the implementation of OSBPs trade facilitation initiative has the effects on the movement of goods across the Rwandan customs posts. However, in order to estimate the extent to which the implementation of OSBPs trade facilitation initiative affects the movement of goods across the Rwandan customs posts, we moderated the relationship between OSBPs initiative and the movement of goods with the level of trade facilitation along the Rwandan customs posts.

According to the results of the random intercept and fixed slope model (Table 6 ), the amount of change in the scores of the movement of goods associated with a 1-unit increase in the level of trade facilitation $\left(\gamma_{01}\right)$ is estimated at 1.255. This therefore suggests that a 1 -unit increase in the level of trade facilitation will improve the movement of goods across the Rwandan customs posts by 1.255 points. Equally important, the results indicate that the effects of OSBPs initiative on the movement of goods are significantly positive. This, in turn, provides an evidence to reject null hypothesis and accept alternative hypothesis that OSBPs trade facilitation initiative has significant positive effects on the movement of goods across the Rwandan customs posts. This is consistent with empirical literature that the OSBP development resulted into significant achievements (Trade Mark 
East Africa, 2016) [44] and significant improvements (Transport Logistics Consultants, 2017) [7].

Relating the results of random intercept and fixed slope model to those of null model in Table 6, it is evident that the addition of the average scores of the level of the implementation of OSBPs initiative in the model has reduced the amount of variance at both levels. The within-group variance has reduced from 0.119 to 0.044 and the between-group variance has reduced from 0.006 to 0.002 . Again, relating both variances, it is obvious that the between-group variances reduction is large. A large reduction in between-group variances means that the distribution of trading agents by the scores of OSBPs trade facilitation initiative differs across the groups of trading agents.

We further extend random intercept and fixed slope model to random intercept and random slope model. Hence, contrary to random intercept and fixed slope model where only the intercept of the regression of the level of trade facilitation was allowed to vary randomly across the groups of trading agents, in this model, both the intercept and slope are allowed to vary randomly across the groups of trading agents. This then allows to test whether the effects of OSBPs trade facilitation initiative vary across the groups of trading agents. To do so, there is a need to carry out the LRT, which is calculated as the difference between the $-2^{\star} \log$-likelihood ratio for null single-level model (Table 7) and the $-2 * \log$-likelihood ratio for random intercept and random slope model (Table 6). The LRT is then equal to $106.611-(-37.343)=143.954$ on 2 d.f. This, therefore, provides an evidence that the group effect differs across the groups of trading agents.

According to the results of the random intercept and random slope model in Table 6, the effects of OSBPs initiative on the movement of goods for the group $j$ is estimated at $-0.061+u_{1 j}$ and between-group variance in the slopes is estimated at 0.001 . Hence, for the average group, 0.061 points decrease in the barriers to the movement of goods is predicted for each increase in the level of trade facilitation across the Rwandan customs posts. Again, a 95\% coverage interval for the group slopes is estimated at $-0.061 \pm 1.96 \sqrt{0.001}=-0.127$ to 0.006 . Thus, it is predicted that the middle $95 \%$ of groups will have a slope between -0.127 and 0.006 if a normal distribution is the assumed.

Table 6 also indicates that the covariance between groups of trading agents' intercepts and slopes or off-diagonal term $\left(\tau_{01}\right)$ is estimated at -0.006 . This, however, gives an impression that the relationship between OSBPs trade facilitation initiative and the movement of goods along the Rwandan customs posts is weak. Equally important, a negative covariance suggests that the two variables move in opposite directions (i.e. inverse relationship). An increase in the level of the implementation of OSBPs trade facilitation initiative will decrease the factors hampering the movement of goods across the Rwandan customs posts. More specifically, the results show that a 1-unit increase in the level of the implementation of OSBPs trade facilitation initiative across the Rwandan customs posts 
will reduce the factors that make the movement of goods complex and more unpredictable by 0.061 point or six point one percent.

Finally, cross-level interaction model is introduced to determine whether the level of trade facilitation moderates the relationship between implementation of OSBPs trade facilitation initiative and the movement of goods across the Rwandan customs posts. According to the results of cross-level interaction model in Table 6, the predicted slope regressing OSBPs trade facilitation initiative on the movement of goods $\left(\gamma_{10}\right)$ is estimated at 0.421 and the cross-level interaction effects $\left(\gamma_{11}\right)$, which is also the interaction term between the level of the implementation of OSBPs trade facilitation initiative and the level of trade facilitation, is estimated at -0.115 .

Such an interaction term suggests that the level of the implementation of OSBPs trade facilitation initiative and the level of trade facilitation are negatively related to the movement of goods along the Rwandan customs posts. This means that a 1-unit increase in the level of trade facilitation will weaken the relationship between OSBPs trade facilitation initiative and the movement of goods across the Rwandan customs posts. Again, a negative amount of the cross-level interaction term indicates that the greater the level of trade facilitation, the weaker the relationship between the level of the implementation of OSBPs trade facilitation initiative and the movement of goods across the Rwandan customs posts.

In sum, the results of this study generally imply that the improvements in the level of the trade implementation of OSBPs initiative across the Rwandan customs posts will enhance the level of trade facilitation along the Rwandan customs posts; and in turn, reduce the factors that make the movement of goods along the Rwandan customs posts complex and unpredictable. In relation to the results of this study, existing literature also reveals that the implementation of OSBPs has reduced time for border crossing (TradeMark East Africa, 2018) [33] and streamlined processes and reduced costs (USAID, 2013) [5].

\section{Conclusions and Recommendations}

This section provides the conclusions and the recommendations basing on the findings of the study. The section starts by the conclusions and ends with the recommendations.

\subsection{Conclusions}

The study assessed the extent to which OSBPs trade facilitation initiative affects the movement of goods along the Rwandan customs posts. The study was nevertheless guided by 4 specific objectives. In terms of the first objective, the level of the implementation of OSBPs trade facilitation initiative along the Rwandan customs posts was rated good. In line with the second objective, the level of trade facilitation along the Rwandan customs posts was also rated very high, meaning that the implementation of OSBPs trade facilitation initiative has immensely contributed to the improvements trade facilitation along the Rwandan 
customs posts. In terms of the third objective, the extent to which the movement of goods has been facilitated was rated high. This implies there has been a reduction in the factors that make the movement of goods complex and unpredictable along the Rwandan customs posts.

As regard the fourth objective, the extent to which the OSBPs trade facilitation initiative affects the movement of goods was estimated using multi-level model. The results of the model therefore suggest that the effects of OSBPs trade facilitation initiative on the movement of goods are significantly positive. This therefore provides an evidence to reject null hypothesis and accept alternative hypothesis that OSBPs trade facilitation initiative has significant positive effects on the movement of goods across the Rwandan customs posts. In brief, the results of this study give an impression that the implementation of OSBPs trade facilitation initiative has not only contributed to the improvements in trade facilitation along the Rwandan customs posts but also reduced to a large extent or removed the barriers to the movement of goods along the Rwandan customs posts.

This study contributes to the existing stock of knowledge in a number of ways. It embraces a mixed approach (qualitative and quantitative) with multi-level model as a holistic approach. Hence, this new approach of methodology substantially contributes to the existing empirics on trade facilitation and its impact. In addition, the dissemination of the findings is particularly important in spreading information about the improvements in the level of trade facilitation along the Rwandan customs posts as the result of the implementation of OSBPs trade facilitation initiative. This would, in turn, attract foreign investors and international development partners.

This study is also significant in that it provides readers with empirical evidence. In that regard, the results steaming from this study should also provide important insights for different trading agents (importers, exporters, transporters, freight forwarders and clearing agents amongst others), policy makers and practitioners as well as other stakeholders and development partners involving in the formulation of policies to understand and discover the current state of trade facilitation environment across the Rwandan customs posts.

However, some limitations were encountered during this study. OSBP is a trade facilitation initiative adopted at the EAC level with the primary objective of facilitating cross-border trade within the community. However, due to several reasons including time factor, this study is geographically limited to Rwanda to assess the effects of OSBPs on the movement of goods along Rwandan customs posts. Hence leaving a gap for which it calls for further studies. In addition, this paper used primary data collected at one point in time. Hence, a replica study involving repeated observations over a long period of time (longitudinal study) can be carried out. Equally important, this paper limits itself on the perceptions of the trading agents on the variables of the study (qualitative data which were further quantified by computing average scores) as a result of a shortage of quantitative secondary data on the level of the implementation of OSBPs and 
trade facilitation along the Rwandan customs posts.

\subsection{Recommendations}

Taking into considerations these results, this study calls for involvement and consultations of all border-crossing agencies and stakeholders in order to enhance implementation of OSBPs and continually improve trade facilitation to respond to the needs of trading agents. Moreover, different agencies involved must be aware of their rights and obligations and endeavour to accomplish them to make the movement of goods smoother and easier. Further study assessing similar variables can be done in other EAC partner states implementing the same initiative to diversify the results of this study and develop common trends.

\section{Conflicts of Interest}

The author declares no conflicts of interest.

\section{References}

[1] World Bank (2012) Rwanda Economic Update. Leverage Regional Integration. 3rd Edition, World Bank, Kigali.

[2] Gasiorek, M., Mendez-Parra, M. and Willenbocked, D. (2017) The Costs of Logistics and Transport Barriers to Trade in East Africa. Policy Briefing, Overseas Development Institute, London.

[3] Chimilila, C., Sabuni, C. and Benjamin, A. (2014) Trade Facilitation in EAC Customs Union: Its Achievement and Implementation in Tanzania. Journal of Economics and Sustainable Development, 5, 1-15.

[4] East African Community (EAC) (2016) The East African Community One Stop Border Posts Act, 2016. The East African Community Official Gazette No. 4 of 15th April 2016. East African Community, Arusha.

[5] United States Agency for International Development (USAID) (2013) Enabling Agricultural Trade Project: Rwanda Cross-Border Agricultural Trade Analysis, February 2013.

https://www.agrilinks.org/sites/default/files/resource/files/USAID-EAT\%20Cross-B order\%20Trade\%20Analysis\%20Rwanda.pdf

[6] Kingombe, C. (2014) Implementing the WTO Trade Facilitation Agreement in Africa: The Role of the African Development Bank. Trade Facilitation Rules as a Trade Enabler: Options and Requirements. African Development Bank Group, Geneva.

[7] Transport Logistics Consultants (2017) Japan International Cooperation Agency Project on Capacity Development for International Trade Facilitation of the Eastern African Region: End Line Time Measurement Survey at the Rusumo Border. Final Report, Transport Logistics Consultants, Nairobi.

[8] Cheruiyot, S. and Rotich, G. (2018) Factors Affecting the Implementation of One Stop Border Post Strategy: A Case Study of the Malaba Border. International Academic Journal of Human Resource and Business Administration, 3, 303-324. http://www.iajournals.org/articles/iajhrba v3 i1 303 324.pdf

[9] Mupayi, S. and Manyeruke, C. (2015) The Impact of the Chirundu One Stop Border Post in Addressing Border Protectionist Challenges. Mediterranean Journal of Social Sciences, 6, 11-20. https://doi.org/10.5901/mjss.2015.v6n6s2p11 
[10] Grainger, A. (2007) Trade Facilitation: A Review (Working Paper). Trade Facilitation Consulting Ltd., London. https://www.tradefacilitation.co.uk

[11] United Nations Conference on Trade and Development (UNCTAD) (2006) Trade Facilitation Handbook Part I-National Facilitation Bodies: Lessons from Experience. United Nations Conference on Trade and Development, Geneva, UNCTAD/ SDTE/TLB/2005/1.

[12] OECD (Organisation for Economic Co-Operation and Development) (2001) Business Benefits of Trade Facilitation. Working Party of the Trade Committee. TD/TC/ WP (2001)21, Organisation for Economic Co-Operation and Development, Paris.

[13] UN-OHRLLS (2013) The Development Economics of Landlockedness: Understanding the Development Costs of Being Landlocked, New York.

[14] Orliac, T. (2012) The Economics of Trade Facilitation. Ph.D. Dissertation, Atelier national de reproduction des theses, Lille.

[15] Kieck, E. (2010) Coordinated Border Management: Unlocking Trade Opportunities through One Stop Border Post. World Customs Journal, 4, 3-14.

http://www.iajournals.org/articles/iajhrba v3 i1 303 324.pdf

[16] Bruce, W., Sydney, C., Kristiaan, B., Koichiro, T., Sue, K., Akie, T. and Paul, K. (2011) OSBP Source Book 1st Edition, September 2011.

https://docplayer.net/20383865-Osbp-source-book-1st-edition-september-2011.htm $\underline{1}$

[17] East Africa Trade Hub (2012) Integrated Border Management. Compete Knowledge Management Technical Bulletin - IBM (September).

[18] PIDA (Programme for Infrastructure Development in Africa) (2006) One-Stop-Border Post Sourcebook. 2nd Edition.

www.au-pida.org/download/one-stop-border-post-sourcebook-2nd-edition/

[19] Polner, M. (2011) Coordinated Border Management: From Theory to Practice. World Customs Journal, 5, 49-64.

[20] Woudsma, C. (2001) Understanding the Movement of Goods, Not People: Issues, Evidence and Potential. Urban Studies, 38, 2439-2455.

https://doi.org/10.1080/00420980120094605

[21] Arvis, J.F., Smith, G. and Carruthers, R. (2011) Connecting Landlocked Developing Countries to Markets: Trade Corridors in the 21st Century. The World Bank, Washington DC. https://doi.org/10.1596/978-0-8213-8416-9

[22] Engman, M. (2005) The Economic Impact of Trade Facilitation. OECD Trade Policy Papers, No. 21, OECD Publishing, Paris.

[23] Asia-Pacific Economic Cooperation (APEC) (2011) Trade Facilitation through Customs Procedures: Assessment of APEC's Progress. Asia-Pacific Economic Cooperation, Melbourne.

[24] Lesser, C. and Moisé-Leeman, E. (2009) Informal Cross-Border Trade and Trade Facilitation Reform in Sub-Saharan Africa. OECD Trade Policy Papers No. 86, OECD Publishing, Paris.

[25] Morgan, R.E. and Katsikeas, C.S. (1997) Theories of International Trade, Foreign Direct Investment and Firm Internationalization: A Critique. Management Decision, 35, 68-78. https://doi.org/10.1108/00251749710160214

[26] Robert, M.D. and John, H.M. (2004) International Economics. 6th Edition, Taylor \& Francis e-Library, New York.

[27] Schumacher, R. (2012) Free Trade and Absolute and Comparative Advantage: A Critical Comparison of Two Major Theories of International Trade. Vol. 16, Un- 
iversitätsverlag Potsdam, Potsdam.

[28] Suranovic, S. (2010) International Trade: Theory and Policy. George Washington University (GW), Washington DC.

[29] Harrigan, J. (2001) Specialization and the Volume of Trade: Do the Data Obey the Laws? Working Paper No. 8675, National Bureau of Economic Research, Cambridge. https://doi.org/10.3386/w8675

[30] Gupta, S.D. (2015) Comparative Advantage and Competitive Advantage: An Economics Perspective and a Synthesis. Athens Journal of Business and Economics, 1, 9-22. https://doi.org/10.30958/ajbe.1-1-1

[31] Shippers Council of Eastern Africa (2015) East Africa Logistics Performance Survey 2012: Cost, Time and Complexity of the East African Logistics Chain. Shippers Council of Eastern Africa, Nairobi.

[32] Tyson, J. (2015) Effect of Sub-Saharan African Trade Corridors on Vulnerable Groups. ODI Report, Overseas Development Institute, London.

[33] TradeMark East Africa (2018) Enhancing Trade and Regional Integration in East Africa: One Stop Border Posts. TradeMark East Africa, Nairobi.

[34] Gashayija, N. (2015, January 12) Importance of One Stop Border Post Facilities in EAC Integration. The New Times.

https://www.newtimes.co.rw/section/read/184873

[35] TradeMark East Africa (2017) TradeMark East Africa Annual Report 2016-2017. TradeMark East Africa, Nairobi.

[36] Daniel, W.W. and Cross, C.L. (2013) Biostatistics: a Foundation for Analysis in the Health Sciences. 10th Edition, John Wiley \& Sons, Hoboken.

[37] George, D. and Mallery, P. (2003) SPSS for Windows Step by Step: Answers to Selected Exercises. A Simple Guide and Reference. Allyn and Bacon, Boston.

[38] Parilla, E.S. (2013) Level of Management Practices of Micro and Small Businesses in Ilocos Norte. International Journal of Academic Research in Business and Social Sciences, 3, 439-466. https://doi.org/10.6007/IJARBSS/v3-i7/67

[39] Saduak, W., Poungsuk, P., Phonpakdee, R. and Deeying, S. (2017) Problem Condition in the Agricultural Learning Center Using at Praibuengwittayakom School, Srisaket Province, Thailand. International Journal of Agricultural Technology, 13, 2117 2124. http://www.ijat-aatsea.com

[40] Mathieson, C. (2016) The Political Economy of Regional Integration in Africa. The East African Community Report. European Centre for Development Policy Management, Mestreech. http://ecdpm.org/peria/eac

[41] Ombudo K., A., Echandi, R., Kusek, P. and Polanco, R.J. (2014) East African Common Market Scorecard 2014: Tracking EAC Compliance in the Movement of Capital, Services and Goods. East African Community, Arusha.

[42] English, P., McSharry, P. and Ggombe, K. (2016) Raising Exports and Attracting FDI in Rwanda. IGC Policy Note, No. 38402, International Growth Centre, London.

[43] Peugh, J.L. (2010) A Practical Guide to Multilevel Modeling. Journal of School Psychology, 48, 85-112. https://doi.org/10.1016/j.jsp.2009.09.002

[44] TradeMark East Africa (2016) TradeMark East Africa Annual Report 2015-2016. TradeMark East Africa, Nairobi. 